\title{
Bacterial Community Associated with Autotrophic and Heterotrophic Cultures of Medicinal Plant Smallanthus sonchifolius (Yacon)
}

\author{
Rita M. Moraes $^{1,2}$, Itamar S. Melo ${ }^{3}$, Joko Sumyanto ${ }^{1,2}$, Suman Chandra ${ }^{1}$, Vaishali Joshi ${ }^{1}$ \\ ${ }^{1}$ National Center for Natural Products Research, Research Institute for Pharmaceutical Sciences, The University of Mississippi, Uni- \\ versity, Oxford, USA; ${ }^{2}$ Center of Water and Wetland Resources, The University of Mississippi Field Station, Abbeville, USA; \\ ${ }^{3}$ EMBRAPA/Environment, Rodovia SP 340 - Km 127.5, Caixa Postal 69, CEP, Jaguariúna SP, Brazil. \\ Email: rmoraes@olemiss.edu
}

Received August $11^{\text {th }}, 2012$; revised September $8^{\text {th }}, 2012$; accepted September $18^{\text {th }}, 2012$

\begin{abstract}
Several unfruitful attempts to grow axenic shoot cultures of Smallanthus sonchifolius, also known as yacon, were made before healthy shoots grew in association with bacteria on half strength Murashigue and Skoog media supplemented with $2.2 \mu \mathrm{M}$ benzylaminopurine. Twenty-one bacterial isolates were obtained from in vitro S. sonchifolius plantlets, eight of these isolates were identified as Flavimonas oryzihabitans, Curtobacterium pusillum, Sphingomonas paucimobilis, and Microbacterium imperiale. These microorganisms produced indole acetic acid (IAA) at amounts varying between 8.89 to $47.45 \mu \mathrm{g} / \mathrm{mL}$, reason for being classified as plant growth promoting bacteria (PGPB). The results show that buds associated with bacteria cultured on sucrose free media produced 3.77 new roots measuring $18.33 \mathrm{~cm}$ in length after a 30-day growing period. In contrast, buds growing on sucrose supplemented media, the number of roots induced was higher (6.67 to 14 roots/explant) but shorter in length, 4.67 to $5.83 \mathrm{~cm}$. During plant acclimatization to soil, photosynthesis and water efficiency were measured showing that the plants were healthy and vigorous. A slightly higher rate of photosynthesis and water use efficiency was recorded in the plants produced on heterotrophic conditions as compared to plants grown in sucrose free media. Plants adapted well in the soil demonstrating that the PGPB community associated to $S$. sonchifolius in shoot cultures was not harmful to plant production. The purpose of this study was to demonstrate that the bacteria associated with in vitro S. sonchifolius shoot cultures was not the result of microbial contamination, but rather from symbiotic associations that extended from cultivation in the greenhouse, to culture and back to soil. This is the first report to show that autotrophic cultures may represent a viable alternative to grow healthy plants without eliminating beneficial bacteria associated with the host.
\end{abstract}

Keywords: Micropropagation; Endophytes; Yacon; IAA; Bacteria

\section{Introduction}

Micropropagation in the horticulture industry is a routine technique used to propagate healthy and elite germplasm. One of the critical steps in micropropagation is the disinfection procedure. Published reports dedicate special attention to protocols used to disinfect different plant tissues and to avoid microbial contamination during the process of plant multiplication [1-3]. Leifert et al. [4] suggest that the elimination of plant parts close to the soil could avoid microbial growth in tissue culture because disinfection of those parts is difficult. According to Hardoim et al. [5], plant rhizospheres are the hot areas of microbial colonization.

Recently, Miller et al. [6] demonstrate that leaf and stem tissues of Traditional Chinese Medicine (TCM) herbs are host to diverse bacteria and fungi with the potential to synthesize secondary metabolites which contribute to the plant's chemical composition and therapeutic properties Our studies on Echinacea immune enhancing properties revealed that lipoproteins and lipopolyssaccharides of bacterial endophytes are the actives responsible for in vitro macrophage activation [7].

In reviewing the biology and chemistry of endophytes, Zhang et al. [8] report that some bacterial endophytes could originate from the rhizophere or phylloplane microbiota, then penetrate and colonize root tissue to gain access to the xylem. Several reports describe endophytic microbiota as beneficial, because they improve the host's adaptability, promote growth, and prevent disease through endophyte-mediated de novo synthesis of compounds with anti-fungal properties [9-11].

Thomas et al. [12] show the ubiquitous presence of 
fastidious endophytic bacteria in apparently clean shoottip cultures of papaya. Cells of axenic peach palm (Bactris gasipaes) microplants were observed by light microscopy and De Almeida et al. [13] analyze the movements of small particles within the cells as intracellular bacterial community. The presence of bacteria in tissue culture is not only the result of poor technique but it may be the result of mutualistic association between the host and its associates. Potential applications of beneficial microorganisms associated with plants still restricted to those amenable to cultivation $[6,14]$. Thus, plant tissue culture may offer a useful system to recover beneficial microorganisms in association with specific organs. Herein, the study describes healthy shoot cultures of Smallanthus sonchifolius Poepp. H. Rob, also known as yacon, growing hetero and autotrophically, while maintaining the consortium between host and associated bacteria.

\section{Material and Methods}

\subsection{Plant Material}

Yacon's rhizophores were donated to the National Center for Natural Products Research by the University of Ribeirao Preto (UNAERP), Department of Biotechnology, Brazil. Stem cuttings were planted in pots and kept under mist system for 15 days in the glasshouse located at University Field Station and later the pots were irrigated by a dripping system, $200 \mathrm{ml}$ per pot on a daily basis. The plant material donated by UNAERP was of a single clone that has been propagated by rhizophores and stem cuttings.

\subsection{Shoot Cultures of Smallanthus sonchifolius}

Terminal buds and nodal segments ( $0.5 \mathrm{~cm}$ long) were harvested from potted plants and washed with running water for 15 minutes. Buds were immersed in $0.5 \%(\mathrm{w} / \mathrm{v})$ sodium hypochlorite solution for 30 minutes, and then washed three times in sterile water. Surface disinfected buds were inoculated on half strength Murashige and Skoog [15] (MS), media supplemented with $3 \%(\mathrm{w} / \mathrm{v})$ sucrose and $2.2 \mu \mathrm{M}$ benzyladenine (BA) solidified with $0.8 \%$ agar, $\mathrm{pH}$ was adjusted to 5.8 . After the third unsucessful attempt to obtain axenic in vitro cultures of $S$. sonchifolius. Five $\mathrm{ml}$ of the third wash used to remove sodium hypochlorite solution of explants, was smeared on bacteriological media showing no signs of bacterial growth.

Half of the shoot cultures associated with bacteria growing epiphytically at the base of explants with no signs of virulence to the host were separated and later half were transferred to sucrose free media using sun cap closures (MKKB7267) to allow gas exchange. These cultures were denominated WOS. The other half of the cul- tures were sub-cultured to the sucrose media called WS media. Twenty days after the inoculation of the explants, cultures were evaluated (Table 1, Figure 1(E)). After the first evaluation, terminal shoots were transferred to MS/2 supplemented with $\mathrm{BA}$ at concentrations ranging from $2.2 \mu \mathrm{M}, 4.4 \mu \mathrm{M}$ and $8.8 \mu \mathrm{M}$ to induce multiple shoots. WOS and WS cultures were evaluated after a 30-day growing period (Table 2). Each treatment had 6 replicates. The experiment was repeated three times. Presence of bacteria was noticed growing epiphytically at the base of the shoot explants in every subculture. Shoot cultures were sent to the microbiology laboratory at EMBRAPA/ Environment, Jaguariuna Brazil for microorganism identification.

S. sonchifolius cultures were maintained in alternating growing conditions with sucrose (WS) and without sucrose (WOS) for more than 12 months in a 30 day interval between subcultures. Thirty day plantlets grown on WOS and WS media (Figures 1(E) and (F)) were submitted to microscopic analysis. The subcultures were done by removing and discarding the roots and the reinoculation of the buds on fresh media. Cultures were always incubated at $25^{\circ} \mathrm{C} \pm 2^{\circ} \mathrm{C}, 16$-h photoperiod under fluorescent light with a photon flux of $52 \mu \mathrm{mol} \cdot \mathrm{m}^{-2} \cdot \mathrm{s}^{-1}$. After 12 months of in vitro alternating cultures (WOS and WS) the $S$. sonchifolius plantlets were acclimatized in the soil and later cultivated in the pots. Photosynthesis rate was measured to evaluate the performance of WOS and WS plants during acclimatization.

\subsection{Microscopic Evaluation of Smallanthus sonchifolius Shoots}

S. sonchifolius/bacteria cultures grown on sucrose free and sucrose containing media were observed both morphologically and micro-morphologically. Hand sections of the shoots were taken for samples growing under autotrophic and heterotrophic conditions; sections were stained with Safranin O and mounted on glass slide with glycerine and observed using Nikon Eclipse E-600. Photomicrographs were taken using Olympus DP-71; images were processed using DP manager (Figures 1(C) and (D)).

Table 1. Effect of explants and growing conditions on the growth of $S$. sonchifolius shoot cultures.

\begin{tabular}{ccccc}
\hline \multirow{2}{*}{ Treatments } & & \multicolumn{2}{c}{ Plant Height \pm} & \# of Roots \pm \\
& SE & Root Length \pm \\
SE & SE \\
\hline Media/Explant Type $^{\dagger}$ & $(\mathrm{cm})$ & & $(\mathrm{cm})$ \\
\hline WOS $^{*}$ & TB & $2.93 \pm 0.85$ & $6.90 \pm 4.00$ & $2.95 \pm 1.98$ \\
WOS & NS & $1.30 \pm 0.76$ & $1.90 \pm 2.57$ & $1.10 \pm 1.34$ \\
WS & TB & $3.20 \pm 0.72$ & $6.60 \pm 2.76$ & $2.99 \pm 1.66$ \\
WS & NS & $1.42 \pm 1.13$ & $1.81 \pm 1.72$ & $1.10 \pm 1.24$ \\
\hline
\end{tabular}

${ }^{\dagger} \mathrm{TB}$ is terminal bud, NS is nodal segment. WOS- $1 / 2$ MS without sucrose, WS- $1 / 2$ MS media with sucrose; Data was recorded after a 20 days of the inoculation. 


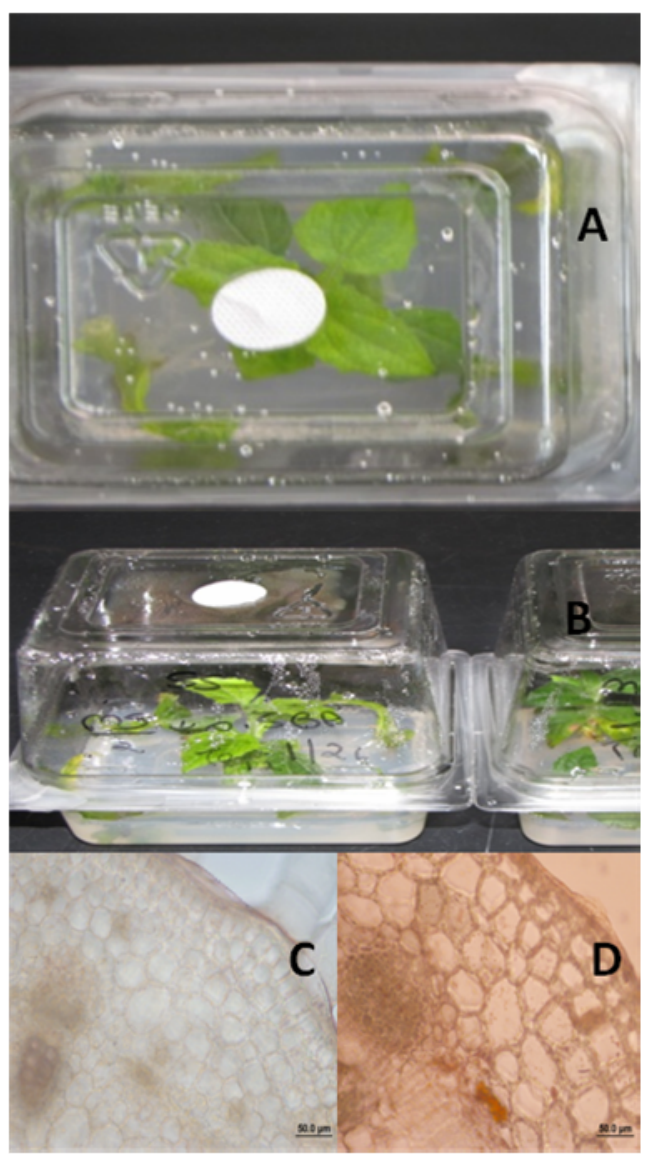

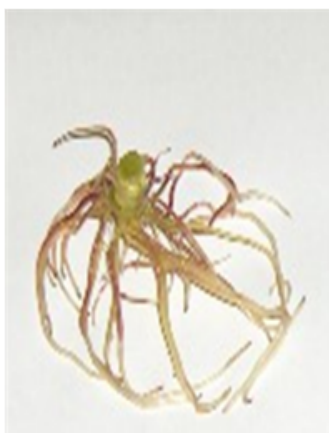

MS/2 with Sugar

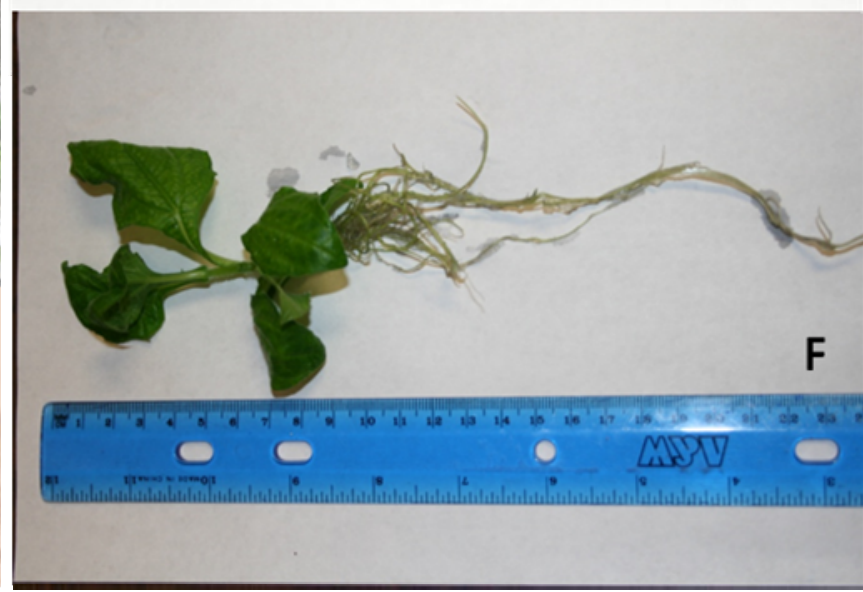

Figure 1. Shows shoots of Smallanthus sonchifolius, also known as yacon, growing on autotrophic cultures in association with bacteria (A) and (B), hand sections of shoots taken for samples growing under autotrophic and heterotrophic conditions (C) and (D), root branching of yacon plantlets produced on sugar free and sugar containing $1 / 2$ MS salts (E); in vitro produced yacon plantlet before acclimatization $(F)$.

Table 2. Effect of benzyladenine on the growth and development of micropropagated cultures of yacon initiated only using only terminal shoot as explants.

\begin{tabular}{|c|c|c|c|c|}
\hline \multicolumn{2}{|c|}{ Treatment } & \multirow{2}{*}{$\begin{array}{c}\text { Plant Height } \pm \text { SE } \\
(\mathrm{cm})\end{array}$} & \multirow[t]{2}{*}{$\#$ of Roots $\pm \mathrm{SE}$} & \multirow{2}{*}{$\begin{array}{c}\text { Root Length } \pm \mathrm{SE} \\
(\mathrm{cm})\end{array}$} \\
\hline Culture condition & $\mathrm{BA}(\mu \mathrm{M})$ & & & \\
\hline \multirow[t]{3}{*}{ WOS } & 2.2 & $6.33 \pm 0.58$ & $5.33 \pm 0.58$ & $17.33 \pm 4.93$ \\
\hline & 4.4 & $4.67 \pm 1.53$ & $3.33 \pm 1.15$ & $21.00 \pm 6.56$ \\
\hline & 8.8 & $4.67 \pm 2.52$ & $2.67 \pm 0.58$ & $16.67 \pm 2.89$ \\
\hline \multirow[t]{3}{*}{ WS } & 2.2 & $4.00 \pm 0.00$ & $6.67 \pm 3.06$ & $5.83 \pm 2.25$ \\
\hline & 4.4 & $3.00 \pm 1.00$ & $14.00 \pm 5.29$ & $4.67 \pm 1.53$ \\
\hline & 8.8 & $3.33 \pm 0.58$ & $10.67 \pm 1.15$ & $4.67 \pm 1.53$ \\
\hline
\end{tabular}

$\mathrm{BA}=$ Benzyladenine, $\mathrm{SE}=$ Standard Error; Data was recorded after a 30 day growing cycle.

\subsection{Isolation, Identification of the in Vitro Community of Bacteria Associated with in Vitro Cultures of Smallanthutus sonchifolius}

In vitro $S$. sonchifolius plantlets were cut in small pieces $(0.5-0.7 \mathrm{~cm})$ and inoculated on Tryptone Soya Agar (TSA) media [16] and on starch (10 g per liter) casein ( $0.3 \mathrm{~g}$ per liter) medium supplemented with $\mathrm{KNO} 2 \mathrm{~g}$; $\mathrm{NaCl} 2 \mathrm{~g}$; $\mathrm{K}_{2} \mathrm{HPO}_{4}, 2 \mathrm{~g} ; \mathrm{MgSO}_{4} \cdot 7 \mathrm{H}_{2} \mathrm{O}, 0.05 \mathrm{~g} ; \mathrm{FeSO}_{4} \cdot 7 \mathrm{H}_{2} \mathrm{O}, 0.01 \mathrm{~g}$; agar, $16 \mathrm{~g}$ per liter). Cultures were maintained at room temperature varying between $25^{\circ} \mathrm{C}$ and $27^{\circ} \mathrm{C}$. Bacteria growth was evaluated 48 hours after inoculation and for a 10 day-period. Cultures were storage in $-70^{\circ} \mathrm{C}$ on glycerol $(20 \% \mathrm{v} / \mathrm{v})$ stocks.

All bacteria were identified by Gram-staining and whole cell fatty acid analysis (FAME) $[17,18]$. For the FAME analysis the isolates were cultures on TSBA medium at $28^{\circ} \mathrm{C}$ for $48 \mathrm{~h}$. Biomass was harvested and the 
fatty acids saponificated, methylated and extracted as described by Millar and Berger [17]. Fatty acid methyl esters were analyzed using an Agilent GC (7683) and the identification was done with the Sherlock Microbial Identification System (MIDI Inc. Newark, DE, USA) and GC analysis. The FAME profile of Xanthomonas maltophilia ATCC 13637 was used as a reference for the MIDI determinations. FAME identification is highly reliable for similarities higher than 0.70 at species level, while lower levels can affiliate isolates to higher taxonomic groups, like genus or families [18].

\subsection{Indole Acetic Acid Production of the Isolated Bacteria from in Vitro Shoot Cultures of Smallanthus sonchifolius}

The production of Indole Acetic Acid (IAA) was determined by the colorimetric methodology described previously by Gordon and Weber [19]. Briefly, isolates were grown in nutrient broth (NB) medium amended with tryptophan $(100 \mu \mathrm{g} / \mathrm{mL})$ in the dark. Cells were harvested by centrifugation $(12,000 \mathrm{~g}$ for $5 \mathrm{~min})$ and the supernatant was treated with Salkovski reagent for $15 \mathrm{~min}$. The production of IAA was direct related to the absorbance measured at $530 \mathrm{~nm}$. Pure IAA was used in cell experiments as a standard.

\subsection{Plantlet Acclimatization}

In vitro propagated $S$. sonchifolius plantlets grown under autotrophic and heterotrophic conditions were transferred to a soil substrate composed of a mixture $(1: 2 \mathrm{v} / \mathrm{v})$ potting soil (Potting Mix MiracleGro 0.140 .14 0.14) and sand (Garden Basic Play Sand, Sims Bark Co, Tuscumbia, AL). Potted plantlets were maintained under mistirrigation watering cycle of 1 min every hour for a period of 6 hours similar to the procedure.

\subsection{Photosynthesis Measurements}

S. sonchifolius plantlets produced on WOS and WS cultures were hardened and used for carbon assimilation and water vapor exchange studies. Measurements were carried out on five upper undamaged, fully expanded and healthy leaves of each plant with the help of a closed portable photosynthesis system (Model LI-6400; LI-COR, Lincoln, Nebraska, USA). Following preliminary experiments on these plants, $\sim 30^{\circ} \mathrm{C}$ was found optimum temperature for growth, and therefore all subsequent gas and water vapor exchange measurements were carried out at $30^{\circ} \mathrm{C} \pm 0.5^{\circ} \mathrm{C}$. To determine the effect of light on gas and water vapor exchange, leaves were exposed to different photosynthetic photon flux densities (PPFD) viz., 0, 500, 1000,1500 and $2000 \mu \mathrm{mol} \cdot \mathrm{m}^{-2} \cdot \mathrm{s}^{-1}$ with the help of an artificial light source (Model LI-6400-02; light emitting silicon diode; LI-COR), fixed on the top of the leaf chamber. Photosynthetically active radiation (PAR) was recorded with the help of a quantum sensor kept in the range of $660-675 \mathrm{~nm}$ wave radiation, fixed at the leaf level. The rate of dark respiration was measured by maintaining the leaf in the cuvette at zero irradiance. The leaf chamber was covered with a black cloth throughout the course of respiration measurements to avoid any external radiation. Air flow rate $\left(500 \mathrm{mmol} \cdot \mathrm{s}^{-1}\right), \mathrm{CO}_{2}$ concentration inside the leaf chamber ( $350 \pm 5 \mathrm{ppm})$, temperature $\left(30^{\circ} \mathrm{C} \pm 0.5^{\circ} \mathrm{C}\right)$ and relative humidity $(55 \% \pm 5 \%)$ were kept nearly constant throughout the experiment. Since steady state photosynthesis is reached within $30-45 \mathrm{~min}$, the leaves were kept for about 45 - 60 min under each set of light conditions before the observations were recorded. Water use efficiency (WUE) was calculated as a ratio of the rate of photosynthesis and transpiration. The data were analyzed using SYSTAT software package [20].

\section{Results}

\subsection{Morphological Evaluation of Plantlets Growing on WOS and WS Cultures}

Preference was given to terminal and nodal segments removed from plants cultivated in the greenhouse to initiate in vitro cultures over rhizophores (the underground tissue containing fructans in Asteraceae). According to Laifert et al. [4] aerial tissues are easier to surface sterilize than underground parts (Table 1). In less than two weeks after in vitro inoculation of the explants, all cultures showed bacteria growing around the shoots. All cultures were discharged and new attempts were made to obtain axenic shoot cultures of S. sonchifolius sugar containing media.

In the third attempt the third wash was smeared on bacteriological media, showing no signs of bacterial growth. Results of Table 1 revealed that buds/bacteria transferred to WOS media grew taller produced fewer and longer roots than buds growing on WS cultures during three weeks (Table 1). Plant height, root length, number of roots, leaf size and shape were morphological parameters evaluated in this study. Complied data (Tables 1-3) show shoots cultured on WOS media produced taller plantlets, parenchyma cells were more elongated. Figure 1 shows in vitro cultures of yacon ((A) \& (B)) a transversal section of the shoots of plants growing in media with and without sucrose ((C) \& (D)), morphological differences on root branching of plantlets grown on media with and without sucrose ((E) \& (F)). Leaf size, shape and petiole, softness and hyper-hydricity of the tissues were morphological differences noticed on plantlets grown under autotrophic conditions. Epidermis and vascular bundles did 
Table 3. Morphological characters of in vitro yacon shoot cultures grown on half strength MS media supplemented with 2.2 $\mu \mathrm{M}$ benzyladenine with or without sucrose (WS and WOS).

\begin{tabular}{|c|c|c|}
\hline Shoot cultures & WS media & WOS media \\
\hline Leaf size & $3.5 \times 2.5 \mathrm{~cm}$ & $4.5 \times 3.5 \mathrm{~cm}$ \\
\hline Shape & Ovate oblong & Oblong \\
\hline Petiole & Cuneat, ca $2 \mathrm{~cm}$, winged & Cuneat ca $2.5 \mathrm{~cm}$ long, \\
\hline Leaf margins & $\begin{array}{l}\text { Slightly undulate rounded teeth with } \\
\text { irregular, wedge shaped }\end{array}$ & $\begin{array}{l}\text { Margins undulate with irregular } \\
\text { shaped margins }\end{array}$ \\
\hline Leaf apex & Acute & Acute \\
\hline $\begin{array}{l}\text { Hair type } \\
\text { abaxial }\end{array}$ & $\begin{array}{l}\text { Densely hairy on adaxial surface, sparse on } \\
\text { abaxial }\end{array}$ & $\begin{array}{l}\text { Densely hairy on adaxial surface, sparse on } \\
\text { abaxial }\end{array}$ \\
\hline
\end{tabular}

not show any significant differences in the two treatments. No sign of toxicity was noticed on the parenchyma cells, epidermis or vascular bundles of shoots grown in association with bacteria.

Buds/bacteria on sugar containing (WS) media supplemented with $4.4 \mu \mathrm{M}$ produced more roots than any other treatment while under autotrophic condition the roots were fewer and longer (Table 2, Figures 1(E) and (F)). In addition, plantlets grown on WS cultures show browning of the lower leaves with small lateral roots induced at the nodes while WOS plantlets had roots that reached $21 \mathrm{~cm}$ long. Most importantly, the shoots showed differences in root branching due to presence of sugar associated with colonies of bacteria growing epiphytically. The elongated roots may be the result of levels of indole acetic acid (IAA) produced by the plant growth promoting bacteria (Table 4).

\subsection{Isolation and Identification of Epiphytic and Endophytic Bacteria Associated with in Vitro Propagated Smallanthus sonchifolius}

A total of 21 bacteria were isolated from in vitro yacon plantlets. Of these bacteria, only two isolates did not match any known species by the FAME technique. Two isolates matched with low similarity index; Rhizobium radiobacter (0.167) and Pseudomonas aeruginosa (0.2548). Included in Table $\mathbf{4}$ are eight isolates that were identified to the species level with similarity index above 0.75 . These isolates synthesized IAA, with in vitro production varying between $8.89 \mu \mathrm{g} / \mathrm{mL}$ to $47.45 \mu \mathrm{g} / \mathrm{mL}$. Our data suggest that the isolates recovered from in vitro yacon cultures were endophytes except for F. oryzihabitans, which grew endo and epiphytically. Several reports indicate that plant growth promoting bacteria are beneficial endophytes growing in association with the host [21-23]. Among the S. sonchifolius isolates, Microbacterium imperiali and Sphingomonas paucimobilis were the highest IAA producers (Table 4).

\subsection{Photosynthesis Performance of in Vitro Propagated Smallanthus sonchifolius during Acclimatization}

Autotrophically (WOS) and heterotrophically (WS) in vitro produced plantlets were evaluated ex vitro by measuring the effect of different photosynthetic photon flux densities (PPFD) on photosynthesis (Pn), dark respiration $(\mathrm{Rd})$, transpiration (E), stomatal conductance (gs), intercellular $\mathrm{CO}_{2}$ concentration $(\mathrm{Ci})$, ratio of intercellular to external $\mathrm{CO}_{2}$ concentration $(\mathrm{Ci} / \mathrm{Ca})$ and water use efficiency (WUE). The rate of photosynthesis increased with increasing light intensity up to $1500 \mu \mathrm{mol} \cdot \mathrm{m}^{-2} \cdot \mathrm{s}^{-1}$ in both types (WOS and WS) plants (Figure 2). However, increment was more pronounced at PPFD below 500 $\mu \mathrm{mol} \cdot \mathrm{m}^{-2} \cdot \mathrm{s}^{-1}$. Maximum rate of photosynthesis $\left(\mathrm{Pn}_{\max }\right)$ was recorded to be $17.08 \pm 2.60 \mu \mathrm{mol} \cdot \mathrm{m}^{-2} \cdot \mathrm{s}^{-1}$ in the plants produced on WS media with active growing bacteria whereas, it was found to be slightly lower $(15.37 \pm$ $\left.2.80 \mu \mathrm{mol} \cdot \mathrm{m}^{-2} \cdot \mathrm{s}^{-1}\right)$ for the plants that were produced on WOS cultures at $1500 \mu \mathrm{mol} \cdot \mathrm{m}^{-2} \cdot \mathrm{s}^{-1}$. Furthermore, exchange of $\mathrm{CO}_{2}$ was found to be adversely affected by light intensities beyond $1500 \mu \mathrm{mol} \cdot \mathrm{m}^{-2} \cdot \mathrm{s}^{-1}$ PPFD in both types of plants. Dark respiration (at $0 \mu \mathrm{mol} \cdot \mathrm{m}^{-2} \cdot \mathrm{s}^{-1} \mathrm{PPFD}$ ) was also found slightly higher in the plants produced under heterotrophic conditions with active growing bacteria as compared to the plants without sugar. The rate of transpiration and therefore, stomatal conductance (Figures 2(a) and (b), respectively) increased considerably with an increase in PPFD up to highest level tested (2000 $\left.\mu \mathrm{mol} \cdot \mathrm{m}^{-2} \cdot \mathrm{s}^{-1}\right)$ in both sets of plants. Values of $\mathrm{E}$ and $\mathrm{gs}$ were however found to be higher in the plants grown under sucrose media (Figure 2(b)). Contrary to gs, Ci was highest, i.e. $364.00 \pm 22.83$ and $360.00 \pm 19.71$ $\mu \mathrm{mol} \cdot \mathrm{m}^{-2} \cdot \mathrm{s}^{-1}$ at zero light for in vitro and ex vitro propagated plants, respectively (Figure 2(b)). The values gradually decreased with increase in PPFD in both cases. Similar to $\mathrm{Ci}, \mathrm{Ci} / \mathrm{Ca}$ ratio also gradually decreased with PPFD up to $500 \mu \mathrm{mol} \cdot \mathrm{m}^{-2} \cdot \mathrm{s}^{-1}$ and then became nearly 
Table 4. Identification of endophytic bacteria isolated from micropropagated yacon cultured on half strength MS media supplemented with sugar and benzylamine.

\begin{tabular}{|c|c|c|c|c|}
\hline Isolates $^{\dagger}$ & Similarity & Plant Tissue & Absorbance & IAA $(\mu \mathrm{g} / \mathrm{mL})$ \\
\hline & Index & & A 530 & \\
\hline Microbacterium imperiale & 0.769 & Leaf & 0.4614 & 41.70 \\
\hline Sphingomonas paucimobilis & 0.788 & Leaf & 0.4727 & 42.74 \\
\hline Curtobacterium pusillum & 0.771 & Leaf & 0.1051 & 8.89 \\
\hline Microbacterium imperiale & 0.892 & Root & 0.524 & 47.45 \\
\hline Sphingomonas paucimobilis & 0.750 & Stem & 0.3838 & 34.55 \\
\hline Flavimonas oryzihabitans & 0.898 & Endo-Root & 0.4285 & 38.67 \\
\hline Flavimonas oryzihabitans & 0.915 & Epi-Root & 0.4084 & 36.82 \\
\hline Flavimonas oryzihabitans & 0.965 & Endo-Stem & 0.4084 & 38.82 \\
\hline
\end{tabular}

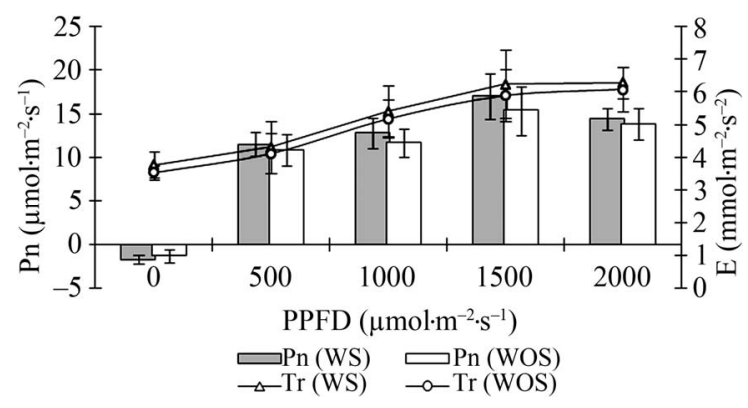

(a)

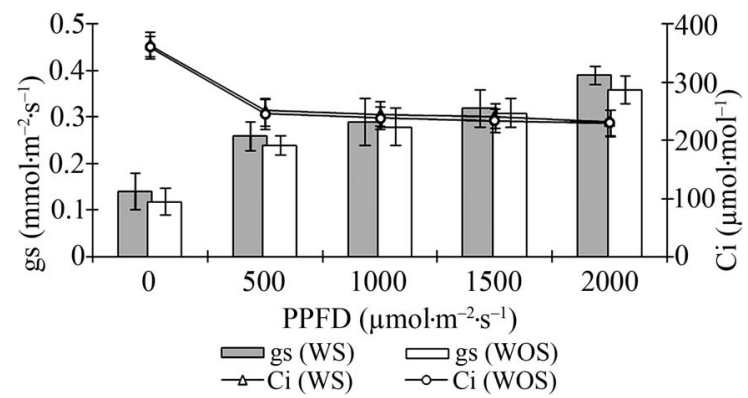

(b)

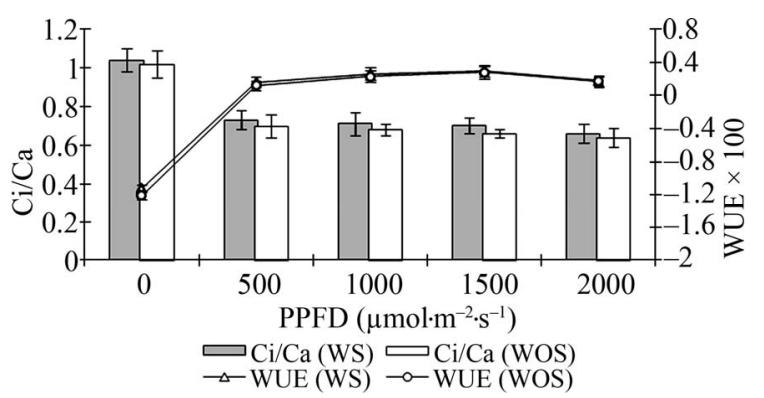

(c)

Figure 2. Effect of photosynthetic photon flux density (PPFD) on (a) photosynthesis, Pn and transpiration, E; (b) stomatal conductance, $\mathrm{Gs}$ and intercellular $\mathrm{CO}_{2}$ concentration, $\mathrm{Ci}$; and (c): ratio of intercellular to ambient $\mathrm{CO}_{2}$ concentration, $\mathrm{Ci} / \mathrm{Ca}$ and water use efficiency, WUE at optimum $\left(30^{\circ} \mathrm{C}\right)$ temperature and relative humidity $(55 \% \pm 5 \%)$ in micropropagated and soil hardened plants of yacon (Smallanthus sonchifolius) produced autotrophically (WOS and heterotrophically (WS). constant for both sets of plants at higher (1000 to 2000 $\mu \mathrm{mol} \cdot \mathrm{m}^{-2} \cdot \mathrm{s}^{-1}$ ) PPFDs (Figure 2(c)). A gradual increase in WUE was recorded with increase in PPFD up to 1500 $\mu \mathrm{mol} \cdot \mathrm{m}^{-2} \cdot \mathrm{s}^{-1}$ and maximum values $(0.30 \pm 0.05$ and 0.28 \pm 0.08 ) for plants produced on media with or without sucrose, respectively were recorded at this level (Figure 2(c)). However, increment was more pronounced at PPFD below $500 \mu \mathrm{mol} \cdot \mathrm{m}^{-2} \cdot \mathrm{s}^{-1}$. A slight decline in WUE was observed at light intensities higher than 1500 $\mu \mathrm{mol} \cdot \mathrm{m}^{-2} \cdot \mathrm{s}^{-1}$ in both sets of plants. Overall, the values of all these parameters were found slightly higher in plants produced on WS media due to presence of actively growing bacteria as compared to the plants growing on WOS media with lesser bacterial growth. It has been shown that plants with higher Pn and WUE have the potential to grow faster and yield more than the species with low Pn and WUE [24,25].

\section{Discussion}

Other in vitro propagation protocols have also described the enrichment of plant growth by endophytic bacteria [26,27] Recently, De Almeida et al. [13] reported that microscopy observations of inner tissues of axenic cultures of Bactris gasipaes were colonized by bacterial cells. Abreu-Tarazi et al. [27] reported the presence of endophytic bacteria in long-term in vitro cultivated "axenic" pineapple microplants. Our study corroborates with these reports by demonstrating that some of bacteria associated with yacon were too difficult to eliminate by surface sterilization procedures. According to Kloepper et al. [28], Pseudomonas, a plant growth promoting bacteria (PGBP) contributed to increase growth and yield of root crops, and seed inoculation with different isolates of PGBP significantly increased plant height, stem diameter, number of branches, number of pods per plant, grain yield and oil content [29]. Most importantly, Vitis vinefera disease-free in vitro produced plantlets were inoculated with PGBP for host protection against plant diseases. Barka et al. [30] reported the beneficial effects of bacterial inoculation aiding plantlets acclimatization to soil condition. 
Soil attached to plant root systems are a hot spot of microbial abundance due to the presence of exudates. According to Compant et al. [31], rhizosphere derived bacteria colonize internal tissues migrating through the xylem to the terminal buds and lateral buds. Thus, surfaced sterilization of terminal buds and nodal segments of yacon did not eliminate the bacteria associated in situ with these tissues. Herein we reported that bacterial growth in association with in vitro shoot cultures was epiphytically and endophytically on WS media. We believe that media containing sugar may have induced bacterial growth out of host tissue, gaining access to other sources of carbon. Although plantlets on WOS cultures did not show any visible signs of bacteria, in vitro culture condition may have contributed to bacterial growth epiphytically. Microscopy evaluations of epidermis and vascular bundles did not show any significant differences between WS or WOS plantlets excepted by the host cell elongation (Figures 1(C) and (D)).

Thomas et al. [12] reported that papaya shoot cultures displayed variation in growth and rooting potential, such variation was attributed to the associated microorganisms. Shoots growing on WS media produced more roots than shoots cultured on WOS. Bacterial colonies surrounding the explants were noticed only on WS media. This observation suggests that media containing sucrose media has stimulated bacterial growth associated to the in vitro rhizopheres. More bacterial growth may have induced greater IAA production leading to great root induction. In fact, browning of the older leaves was noticed on WS plantlets due to accelerated bacterial growth which may have decreased nutrient availability to the host. S. sonchifolius shoot cultures derived from a single clone, thus we attributed the differences in root branching to the presence of sucrose and the enhanced bacterial growth, and perhaps to growth promoters compounds released to the media. Results in Table 4 confirmed that the bacteria associated with yacon were IAA producers, however further studies are needed to determine that bacteria have released auxin in large amounts to shoot cultures causing differences in root branching.

Acclimatization of WS plantlets to soil out performed to WOS plantlets with their long roots (data not shown). The rate of photosynthesis was slightly better for WS plants than WOS. Although, the WOS plantlets had the chloroplast fully functional during in vitro cultivation and prior to acclimatization to soil, the WS plants had more roots to support the transference to soil. In addition, the outgrowth of bacteria associated with WS plantlets rhizophere was highly beneficial during acclimatization providing better resistance to stress.

In conclusion, to our knowledge this is the first report to demonstrate plant growth promoting bacteria (PGPB) in vitro shoot cultures of $S$. sonchifolius. Autotrophic cultures may represent a viable alternative to grow healthy plants without eliminating beneficial bacteria associated with the host. In fact, in vitro protocols may become tool to examine cryptic endophyte consortia associated with embryonic plant tissues.

\section{Acknowledgements}

This research was partially funded by a grant from the USDA, Agricultural Research Service Specific Cooperative Agreement No. 58-6408-7-012. The authors thank Dr. Luiz Rosa for his critique.

\section{REFERENCES}

[1] C.-Y. Ko, A. M. Al-Abdulkarim, S. M. Al-Jowid and A. Al-Baiz, "An Effective Disinfection Protocol for Plant Regeneration from Shoot Tip Cultures of Strawberry," African Journal of Biotechnology, Vol. 8, No. 11, 2009, pp. 2611-2615.

[2] E. Bunn and B. Tan, "Microbial Contaminants in Plant Tissue Culture Propagation,” In: K. Sivasithamparan, K. W. Dixon and E. L. Barrett, Eds., Microorganisms in Plant Conservation and Biodiversity, Kluwer Academic Publishers, 2002, pp. 307-335.

[3] C. Lefiet and A. C. Cassells, "Microbial Harzards in Plant Tissue and Cell Cultures," In Vitro Cellular and Developmental Biology-Plant, Vol. 37, 2001, pp. 133-138.

[4] C. Leifert, C. E. Morrisand and W. M. Waites, "Ecology of Microbial Saprophytes and Pathogens in Tissue-Culture and Field-Grown Plants-Reason for Contamination Problems in Vitro," Critical Review Plant Science, Vol. 13, No. 2, 1994, pp. 139-183.

[5] P. R. Hardoim, L. S. van Overbeek and J. D. van Elsas, "Properties of Bacterial Endophytes and Their Proposed Role in Plant Growth," Trends in Microbiology, Vol. 16, No. 10, 2008, pp. 463-471. doi:10.1016/j.tim.2008.07.008

[6] K. I. Miller, C. Qing, D. M. Y. Sze and B. A. Neilan, "Investigation of the Biosynthetic Potential of Endophytes in Traditional Chinese Anticancer Herbs," PLOS ONE, Vol. 7, No. 5, 2012, e35953. doi:10.1371/journal.pone.0035953

[7] H. Tamta, N. D. Pugh, P. Balachandran, R. M. Moraes, J. Sumiyanto and D. S. Pasco, "Variability in in Vitro Macro-Phage Activation by Commercially Diverse Bulk Echinacea Plant Material Is Predominantly Due to Bacterial Lipoproteins and Lipopolysaccharides," Journal of Agricultural and Food Chemistry, Vol. 56, No. 22, 2008, pp. 10552-10556. doi:10.1021/jf8023722

[8] H. W. Zhang, Y. C. Song and T. X. Tan, "Biology and Chemistry of Endophytes," Natural Products Reports, Vol. 23, No. 5, 2006, pp. 753-771. doi:10.1039/b609472b

[9] G. Berg, L. Eberl and A. Hartmann, "The Rhizosphere as a Reservoir for Opportunistic Human Pathogenic Bacteria," Environmental Microbiology, Vol. 7, No. 11, 2001, 
pp. 1673-1685. doi:10.1111/j.1462-2920.2005.00891.x

[10] E. Bent and C. P. Chanway, "The Growth-Promoting Effects of a Bacterial Endophyte on Lodgepole Pine Are Partially Inhibited by the Presence of Other Rhizobacteria," Canadian Journal of Microbiology, Vol. 44, No. 10, 1998, pp. 980-988. doi:10.1139/w98-097

[11] G. Strobel, B. Daisy, U. Castillo and J. Harper, "Natural Products from Endophytic Microorganisms," Journal of Natural Products, Vol. 67, No. 2, 2004, pp. 257-268. doi:10.1021/np030397v

[12] P. Thomas, S. Kumari, G. K. Swarna, D. P. Prakash and M. R. Dinesh, "Ubiquitous Presence of Fastidious Endophytic Bacteria in Field Shoots and Index-Negative Apparently Clean Shoot-Tip Cultures of Papaya," Plant Cell Reports, Vol. 26, No. 9, 2007, pp. 1491-1499. doi:10.1007/s00299-007-0363-2

[13] C. V. De Almeida, F. D. Andreote, R. Yara, F. A. O. Tanaka, J. L. Azevedo and M. De Almeida, "Bacteriosomes in Axenic Plants: Endophytes as Stable Endosymbionts," World Journal of Microbiology and Biotechnology, Vol. 25, No. 10, 2009, pp. 1757-1764. doi:10.1007/s11274-009-0073-8

[14] B. Reiter and A. Sessitsch "Bacterial Endophytes of the Wildflower Crocus albiflorus Analyzed by Characterization of Isolates and by a Cultivation-Independent Approach," Canadian Journal of Microbiology, Vol. 52, No. 2, 2006, pp. 140-149.

[15] T. Murashige and F. Skoog, "A Revised Medium for Rapid Growth and Bioassays with Tobacco Tissue Cultures," Physiologia Plantarum, Vol. 15, 1962, pp. 473-497. doi:10.1111/j.1399-3054.1962.tb08052.x

[16] W. L. Araujo, W. Maccheroni Jr., C. I. Aguilar-Vildoso, P. A. V. Barroso, H. O. L. Saridakis and J. L. Azevedo, "Variability and Interactions between Endophytic Bacteria and Fungi Isolated from Leaf Tissues of Citrus Rootstocks," Canadian Journal of Microbiology, Vol. 47, No. 3, 2001, pp. 229-236. doi:10.1139/w00-146

[17] L. Miller and T. Berger, "Bacterial Identification by Gas Chromatography of Whole Cell Fatty Acids," Avondale, Pa.: Hewlett-Packard, Hewlett-Packard Application Note, 1985, pp. 1-8.

[18] J. Heyrman, J. Mergaert, R. Denys and J. Swings, "The Use of Fatty Acid Methyl Ester Analysis (FAME) for the Identification of Heterotrophic Bacteria Present on Three Mural Paintings Showing Severe Damage by Microorganisms," FEMS Microbiology Letters, Vol. 181, No. 1, 1999, pp. 55-62. doi:10.1111/j.1574-6968.1999.tb08826.x

[19] S. A Gordon and R. P. Weber, "Colorimetric Estimation of Indoleacetic Acid," Plant Physiology, Vol. 26, No. 1, 1951, pp. 192-195.

[20] SYSTAT, Software Inc. San Jose, USA.

[21] S. Lee, M. Flores-Encarnacion, M. Contreras-Zentella, L. Garcia-Flores, J. Escamilla and C. Kennedy, "Indole-3acetic Acid Biosynthesis Is Deficient in Gluconacetobacter diazotrophicus Strains with Mutations in Cytochrome
C Biogenesis Genes,” Journal of Bacteriology, Vol. 186, No. 16, pp. 5384-5391.

[22] R. Mendes, A. A. Pizzirani-Kleiner, W. L. Araujo and J. M. Raaijmakers, "Diversity of Cultivated Endophytic Bacteria from Sugarcane: Genetic and Biochemical Characterization of Burkholderia cepacia Complex Isolates," Applied Environmental Microbiology, Vol. 73, 2007, pp 7259-7267. doi:10.1128/AEM.01222-07

[23] A. C. F. Dias, E. F. C. Costa, F. D. Andreote, P. T. Lacava, M. A. Teixeira, L. C. Assumpção, W. L. Araújo, J. L. Azevedo and I. S. Melo, "Isolation of Micropropagated Strawberry Endophytic Bacteria and Assessment of Their Potential for Plant Growth Promotion," World Journal of Microbiology and Biotecnology, Vol. 25, No. 2, 2009, pp 189-195. doi:10.1007/s11274-008-9878-0

[24] H. J. Jones, "Plants and Microclimate: A Quantitative Approach to Environmental Plant Physiology," 2nd Edition, Cambridge University Press, Cambridge, 1992.

[25] J. W. Zhang, J. D. Marshall and L. Fins, "Correlated Population Differences in Dry Matter Accumulation, Allocation and Water Use Efficiency in Three Sympatric Conifer Species," Forest Science, Vol. 42, No. 2, 1996, pp. 242-249.

[26] I. Zaspel, A. Ulrich, B. Boine and T. Stauber, "Occurrence of Culturable Bacteria Living in Micropropagated Black Locust Cultures (Robinia pseudoacacia L.)," European Journal of Horticultural Science, Vol. 73, No. 5, 2008, pp. 231-235.

[27] M. F. Abreu-Tarazi, A. A. Navarrete, F. D. Andreote, C. V. Almeida S. M. Tsai and M. Almeida, "Endophytic Bacteria in Long-Term in Vitro Cultivated 'Axenic' Pineapple Microplants Revealed by PCR-DGGE," World Journal of Microbiology and Biotechnology, Vol. 26, No. 3, 2010, pp. 555-560.

[28] J. W. Kloepper, M. N. Schroth and T. D. Miller, "Effects of Rhizosphere Colonization by Plant Growth-Promoting Rhizobacteria on Potato Plant Development and Yield," Phytopathology, Vol. 70, 1980, pp. 1078-1082. doi:10.1094/Phyto-70-1078

[29] H. Asghar, Z. Zahir, M. Arshad and A. Khaliq, "Relationship between in Vitro Production of Auxins by Rhizobacteria and Their Growth-Promoting Activities in Brassica juncea L.," Biology and Fertility of Soils, Vol. 35, No. 4, 2002, pp. 231-237. doi:10.1007/s00374-002-0462-8

[30] E. A. Barka, A. Belarbi, C. Hachet, J. Nowak and J.-C. Audran, "Enhancement of in Vitro Growth and Resistance to Gray Mould of Vitis vinifera Co-Cultured with Plant Growth-Promoting Rhizobacteria," FEMS Microbiology Letters, Vol. 186, No. 1, 2000, pp. 91-95.

[31] S. Compant, C. Clement and A. Sessitsch, "Plant GrowthPromoting Bacteria in the Rhizo and Endosphere of Plants: Their Role, Colonization, Mechanism Involved and Prospect for Utilization," Soil Bioogy and Biochemistry, Vol. 42, 2010, pp. 669-678. doi:10.1016/j.soilbio.2009.11.024 